\title{
Current Therapeutic Strategies in Diabetic Foot Ulcers
}

\author{
Aurelio Perez-Favila ${ }^{1,2}$, Margarita L Martinez-Fierro ${ }^{1,2, * \mathbb{D}}$, Jessica G Rodriguez-Lazalde ${ }^{1}$, \\ Miguel A Cid-Baez ${ }^{1}$, Michelle de J Zamudio-Osuna ${ }^{3}$, Ma. del Rosario Martinez-Blanco ${ }^{2}$, \\ Fabiana E Mollinedo-Montaño ${ }^{4}$, Iram P Rodriguez-Sanchez ${ }^{5}{ }^{\oplus}$, Rodrigo Castañeda-Miranda ${ }^{2}$ \\ and Idalia Garza-Veloz 1,2,*iD \\ 1 Molecular Medicine Laboratory, Unidad Academica de Medicina Humana y Ciencias de la Salud, \\ Universidad Autonoma de Zacatecas, Carretera Zacatecas-Guadalajara Km.6. Ejido la Escondida, C.P., \\ Zacatecas 98160, Mexico; chaure7@gmail.com (A.P.-F.); rodriguezlazaldej@yahoo.com (J.G.R.-L.); \\ drcidbaez@uaz.edu.mx (M.A.C.-B.) \\ 2 Posgrado en Ingenieria y Tecnologia Aplicada, Unidad Academica de Ingenieria Electrica, Universidad \\ Autonoma de Zacatecas, Av. Ramon Lopez Velarde No. 801, Col. Centro, C.P., Zacatecas 98000, Mexico; \\ mrosariomb@yahoo.com.mx (M.d.R.M.-B); rcastm@gmail.com (R.C.-M.) \\ 3 Bioss Celulas Madre, Av. Gomez Morin No. 1200, Carrizalejo, C.P., San Pedro Garza Garcia 66254, \\ Nuevo Leon, Mexico; michellezamudiosuna@gmail.com \\ 4 Unidad Academica de Enfermeria, Universidad Autonoma de Zacatecas, Carretera Zacatecas-Guadalajara \\ Km.6. Ejido la Escondida, C.P., Zacatecas 98160, Mexico; fabianamollinedo@yahoo.com \\ 5 Laboratorio de Fisiologia Molecular y Estructural, Facultad de Ciencias Biologicas, Universidad Autonoma \\ de Nuevo Leon, C.P., San Nicolas de los Garza 66455, Nuevo Leon, Mexico; iramrodriguez@gmail.com \\ * Correspondence: margaritamf@uaz.edu.mx (M.L.M.-F.); idaliagv@uaz.edu.mx (I.G.-V.)
}

Received: 2 September 2019; Accepted: 21 October 2019; Published: 25 October 2019

\begin{abstract}
Diabetic foot ulcers (DFUs) are the fastest growing chronic complication of diabetes mellitus, with more than 400 million people diagnosed globally, and the condition is responsible for lower extremity amputation in $85 \%$ of people affected, leading to high-cost hospital care and increased mortality risk. Neuropathy and peripheral arterial disease trigger deformities or trauma, and aggravating factors such as infection and edema are the etiological factors for the development of DFUs. DFUs require identifying the etiology and assessing the co-morbidities to provide the correct therapeutic approach, essential to reducing lower-extremity amputation risk. This review focuses on the current treatment strategies for DFUs with a special emphasis on tissue engineering techniques and regenerative medicine that collectively target all components of chronic wound pathology.
\end{abstract}

Keywords: therapy; tissue engineering; diabetic foot ulcers

\section{Introduction}

Diabetes mellitus (DM) is a metabolic disorder characterized mainly by the presence of chronic hyperglycemia due to a deficiency of insulin secretion or insulin resistance [1]. The International Diabetes Federation (IDF) reported 425 million people globally with DM in 2017 [2].

Chronic complications of the disease vary according to the type of diabetes, time since onset, and degree of metabolic control, with the most prevalent being the following: neuropathy, 25\%; retinopathy, 32\%; and nephropathy, 23\% [3]. The diabetic foot ulcer (DFU) is a complication of DM, with an annual incidence of $2.4-2.6 \%$ and a prevalence of $4-10 \%$ [4]. It is estimated that the rate of recurrence of DFUs is more than $50 \%$ after three years [5]. These complications constitute an increasing public health problem and are a leading cause of hospital ingress, amputation, and mortality in diabetes patients [6]. The economic impact of DFUs is significant. According to data from the IDF, USD 727 billion is spent on total DM health expenses in people aged 20-79 years [2]. 
Educating patients about podiatric care could prevent DFU development, and reduce their incidence. Understanding of the etiology of ulceration is essential to identify the tissue at risk of ulcerating and to enable proper preventive care, thereby reducing the incidence of foot lesions and, ultimately, amputations [7].

\section{Etiology of Diabetic Foot Ulcers}

For the appearance of a DFU, the convergence of several factors is necessary: usually, an initial injury (trauma) that is not detected by the patient because of an existing neuropathy, together with a peripheral vascular disease. The acquisition of an infection is a common origin of a DFU that can progress to a partial or complete lower limb amputation if not treated properly $[8,9]$.

\subsection{Diabetic Peripheral Neuropathy}

Diabetic peripheral neuropathy (DPN) is defined as the presence of symptoms and/or signs of peripheral nerve dysfunction in people who have DM after excluding other causes [10]. DPN is the most common chronic complication in the lower limbs with a prevalence of over $60 \%$ in people with DM [11]. The effect on sensory, motor, and autonomic nerves can modify the ability of the patient to perceive certain stimuli such as pain, temperature, pressure, and touch [12]. Motor neuropathy can affect the small muscles of the foot causing atrophy; weakness; toe deformities; prominent metatarsals; and, in turn, limited joint mobility. On the other hand, autonomic neuropathy reduces sweating and increases temperature; combined with injuries that are not detected in time, limited mobility of joints, and deformity of the lower extremities associated with DPN, it can cause cracking of the skin, inflammation, and tissue necrosis, ultimately leading to the development of a DFU [9].

\subsection{Peripheral Arterial Disease}

Hyperglycemia together with oxidative stress produces the final products of advanced glycation, which are involved in the development of microvascular and macrovascular complications in people with DM [13]. Peripheral arterial disease (PAD) is a vascular condition characterized by atherosclerotic occlusive disease of the lower extremities that has been found in approximately $30 \%$ of patients with a DFU [14]. Their development is a gradual process, in which the artery becomes blocked, narrowed, or weakened, and, in addition to prolonged inflammation within the microcirculation, leads to thickening of the capillary, thus limiting the elasticity of capillaries leading to ischemia [9]. Related to atherosclerosis is media sclerosis Mönckeberg (MSM), which is frequent in type $2 \mathrm{DM}$, and is associated with progressive calcifications of the arterial wall media, leaving the intima intact [15]. MSM may interfere with compensatory remodeling of the arterial walls, and may accelerate the stenotic phase of the atherosclerosis $[15,16]$. PAD alone is not a cause of a DFU, but aggravates the damage caused by the combination of several risk factors such as DPN, foot deformities, skin dryness, trauma, and infection, enhancing the DFU development [8].

\subsection{Infection}

When a DFU appears, it is susceptible to the onset of infections, mainly owing to prolonged environmental exposure of the wound; pathogen-related factors such as density, virulence, and interactions; and immune defects linked to the host [9]. Several immunological defects have been reported in patients with DM, such as altered phagocytosis and bactericidal activity of polymorphonuclear cells; impaired chemotaxis and phagocytosis functions of monocyte/macrophage; disturbances of cellular innate immunity, including a low serum level of complement factor 4 (C4) and abnormal production of cytokines by monocytes [17]; and alteration of lymphocytes subpopulations and immunoglobulins levels [18]. These abnormalities, mostly related to innate immunity, seem to play a role in the susceptibility of diabetic patients to infections, particularly by resistant pathogens [19].

Infections in DFUs further aggravate the wound healing process, being responsible for frequent visits to the hospital and constituting the main complication that leads to non-traumatic amputations 
of lower limbs in patients with DM $[20,21]$. Approximately $58 \%$ of people who have a DFU will have an infection [22].

A great diversity of pathogenic and non-pathogenic microorganisms live on the skin of humans. Generally, three to five species of different microorganisms are found in an infected DFU, including the following: gram-positive aerobes (Staphylococcus aureus, Staphylococcus epidermidis, Corynebacterium spp.); gram-positive anaerobes (Enterococcus spp., Propionibacterium spp., Streptococcus spp., Peptostreptococcus spp., Peptococcus spp.); gram negative aerobes (Pseudomonas aeruginosa, Acinetobacter spp.); gram negative anaerobes (Proteus mirabilis, Escherichia coli, Bacteroides spp.); and fungi (Candida spp.) [23,24]. In low-income countries, there is a higher prevalence of gram-negative pathogens, the most common of which is Pseudomonas aeruginos [25,26].

\section{Wound Healing Process in Diabetes Mellitus}

A major problem with diabetic wounds is that they do not follow the normal process of wound healing, that is, the dynamic process comprising four phases: hemostasis, inflammation, proliferation, and remodeling (Figure 1).

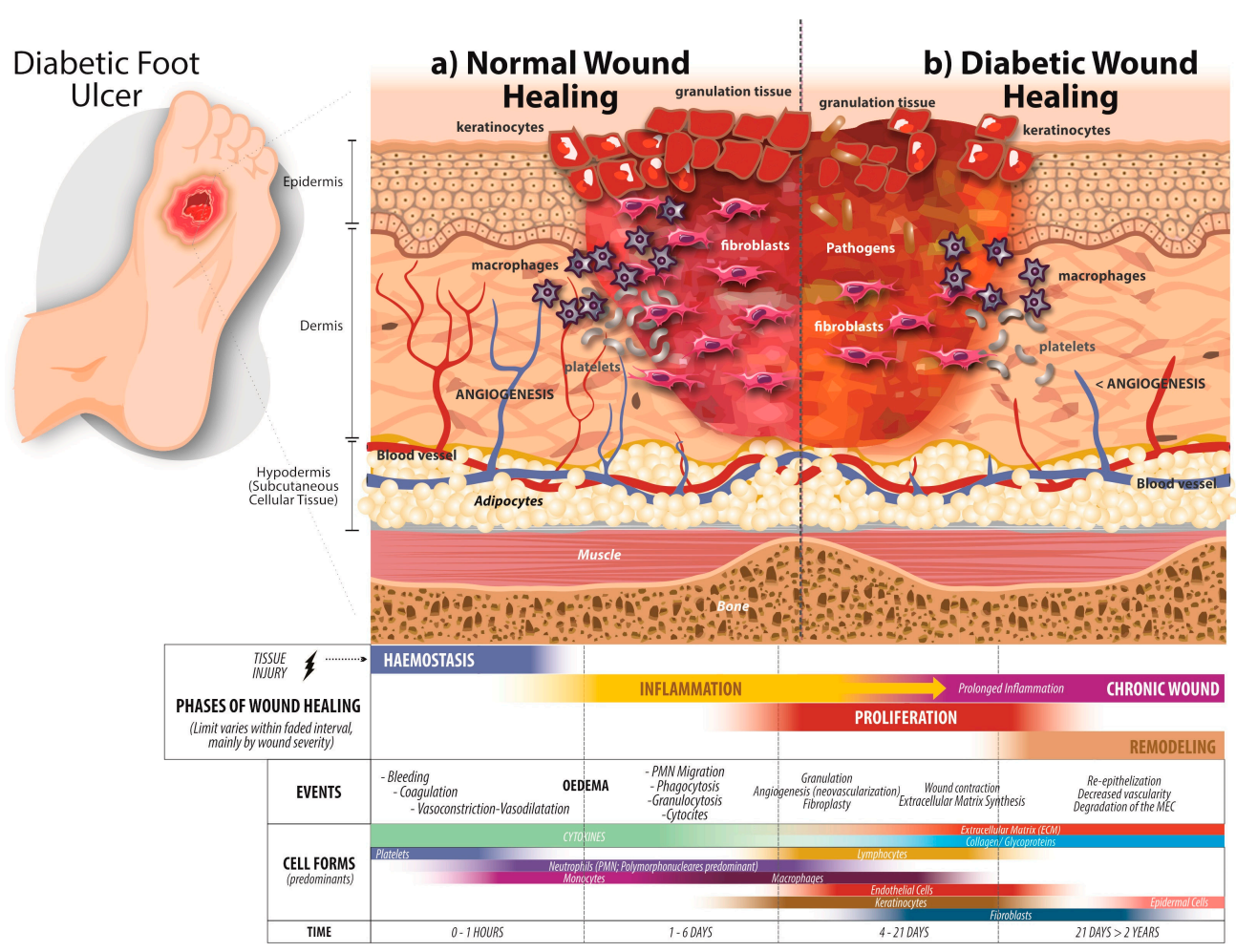

Figure 1. Wound healing process in diabetes mellitus. (a) Normal wound healing. In healthy people, wound closure consists of several processes that occur sequentially: the rapid hemostasis that involves platelet aggregation to form the platelet plug; an inflammation phase where neutrophils, macrophages, and mast cells release proinflammatory cytokines; wound contraction when inflammation decreases, angiogenesis occurs, keratinocytes and fibroblasts migrate, and the extracellular matrix forms; and, finally, the remodeling phase, where granulation tissue converts into mature scar tissue. (b) Diabetic wound healing. In patients with diabetes mellitus (DM), the wound closure processes are affected, starting with a decrease in fibrinolysis and an imbalance of cytokines, which causes an alteration in wound closure. There is also a decrease in angiogenesis due to hyperglycemia, and the migration of cells such as keratinocytes and fibroblasts is diminished, causing deficient re-epithelialization; in the same way, the poor production of the extracellular matrix (ECM) by fibroblasts contributes to the problem of a deficient wound closure. 


\subsection{Hemostasis}

The first phase of the cell repair process involves platelet activation, aggregation, and adhesion to the damaged endothelium to maintain hemostasis, a phenomenon known as coagulation. Once this process is initiated, fibrinogen becomes fibrin, forming the thrombus and the temporary extracellular matrix (ECM). Other cells, such as activated platelets, neutrophils, and monocytes, which release some proteins and various growth factors, such as platelet-derived growth factor (PDGF) and transforming growth factor $\beta$ (TGF- $\beta$ ), also participate [27]; see Figure 1a. Compared with normal subjects, hypercoagulability and a decrease in fibrinolysis are some of the changes in the hemostasis phase that have been observed in patients with DM [28].

\subsection{Inflammation}

An inflammatory process take place when a tissue injury occurs, because the neutrophils, macrophages, and mast cells are responsible for producing inflammatory cytokines, such as interleukin 1 (IL-1), interleukin 6 (IL-6), tumor necrosis factor-alpha (TNF- $\alpha$ ), and interferon gamma (IFN- $\gamma$ ), as well as several growth factors, such as PDGF, epidermal growth factor (EGF), and insulin-like growth factor 1 (IGF-1), which are fundamental in the wound repair process [29,30]. In patients with $\mathrm{DM}$, there exists a disequilibrium of these cytokines that leads to a modification of wound repair [31]. It has been reported that neutrophils present an altered cytokine release pattern and show a decrease in their functionality, and thus contribute to the susceptibility to wound infection [32].

\subsection{Proliferation and Migration}

When inflammation decreases, several processes start at the site of the lesion: wound contraction occurs; angiogenesis takes place to restore the oxygen supply; and ECM proteins form, including collagens, fibronectin, and vitronectin, which are necessary for cell movement, in addition to the migration of keratinocytes. All these processes are necessary for the tissue to recover its integrity and functionality [33].

Owing to hyperglycemia, the migration of fibroblasts and keratinocytes, as well as their proliferative capacity, is diminished in patients with DM. Abnormal cell migration causes a deficient re-epithelialization of the diabetic wound, affecting the healing process [27,34]. In addition, in DM patients, a decrease in angiogenesis and, therefore, a decrease in blood flow, have also been reported [35]; see Figure $1 b$.

\subsection{Remodeling Phase}

This phase starts approximately one week after wound healing and can last more than six months. Here, collagen that is synthesized is greater than that which is degrading and replaces the provisional ECM that was initially formed by fibrin and fibronectin. This granulation tissue becomes mature scar tissue and also increases the wound resistance, ending in the formation of a scar [36].

The fibroblasts of patients with DM are altered in their function, which contributes to defective closure of the wound; although the mechanism is not well known, it is believed that it is because of the fact that they do not respond to the action of TGF- $\beta$, as well as the aberrant production of the ECM [37].

\section{Treatments for Diabetic Foot Ulcers}

One strategy for the management of patients with a DFU is to introduce a multidisciplinary approach and address the multifactorial processes involved in DFUs. The use of multi-disciplinary teams (MDTs) that include all relevant specialties (i.e., nursing, orthopedics, plastic surgery, vascular surgery, nutrition, and endocrinology departments) has shown an effect of decreasing the risks associated with DFUs and amputation by $50-85 \%$, lowering costs, and leading to a better quality of life for patients with DFUs [38]. 
Management of DFUs requires the correct classification of stage and severity. Adequate care for DFUs should include a focus on DM control as well as on wound care, proper infection control, relieving pressure, and optimizing blood flow [39]. The basic care for the control and treatment of DFUs is focused on the management of adequate perfusion, pressure mitigation, control of infection, and debridement [40]. With technological advancement, other series of therapies for DFUs have been implemented, such as the development of skin substitutes, negative pressure wound therapy, hyperbaric oxygen, the creation of new wound dressings that include growth factors, and the use of tissues from bioengineering. In this way, treatments for DPN, PAD, and infections have provided encouraging results $[39,41]$.

\subsection{Treatments for Diabetic Peripheral Neuropathy}

DPN is a factor that increases the risk of the appearance of a DFU, owing to the loss of sensation in the limb, making patients vulnerable to trauma [42]. Tight glycemic control is the primary step and a main feature of DPN management [43]. Normoglycemia is more effectively restored by a pancreas transplant [44]. Several studies have demonstrated improvement of motor and sensory neuropathy in patients with DPN after they were treated with a pancreas transplant. However, discrepancies exist in the time of response $[43,44]$.

Pharmacological treatment is used for painful DPN manifested as numbness, burning, stabbing, or excruciating or intractable pain; only three treatments are approved by the U.S. Food and Drug Administration for the pain associated with DPN, namely, pregabalin, tapentadol, and duloxetine [45].

Another pharmacological therapy includes analgesics, such as tramadol, acetaminophen, and some opioids such as oxycodone, which have constipation and nausea as side effects, and must be taken with care because they can be misused [46]. Therapy with antidepressants such as amitriptyline, nortriptyline, and venlafaxine, among others, has shown an efficacy in neuropathic pain management. It has an effect on the recapture of noradrenaline and serotonin, as well as on muscarinic effects. In spite of this, there are limited studies evaluating these drugs because their doses in clinical trials are not entirely reproducible in clinical practice [47].

Alpha-lipoic acid (ALA) has been suggested as a potential therapeutic agent in treating DPN; its antioxidant capacity seems to delay or reverse damages to peripheral nerves. Several human randomized controlled trials (RCTs) have investigated the effects of ALA in the development of diabetic nephropathy. A meta-analysis of four RCTs $(n=653)$ showed that, compared with placebo, intravenous ALA (600 mg per day) decreased symptoms of neuropathy when administered for three weeks, but symptom improvement with oral ALA ( $>600 \mathrm{mg}$ per day for 3-5 weeks) was not clinically significant. There is no evidence evaluating long-term treatment [48].

Currently, treatments based on the use of mesenchymal stem cells (MSC) derived from adipose tissue have been considered as a potential treatment against DPN. These therapies promote the production of pro-angiogenic, neuroprotective, and anti-inflammatory factors, which have a positive impact on the clinical manifestations of the disease [49].

On the other hand, the use of biological therapy with low doses of IL-6 has been demonstrated to promote improvement of blood flow, decrease chronic inflammation, and regenerate peripheral nerve fibers. Accordingly, IL-6 may prove to be an effective treatment for the protection and/or restoration of peripheral nerve function in DPN [50]; see Table 1. 
Table 1. Therapeutic strategies for diabetic foot ulcer (DFU) management.

\begin{tabular}{|c|c|c|c|c|}
\hline Therapy for & Method & Advantage & Disadvantage & Reference \\
\hline \multirow{6}{*}{ Neuropathic Ulcer } & $\begin{array}{l}\text { Anticonvulsants: Gabapentin, } \\
\text { Pregabalin }\end{array}$ & Neuropathic pain reduction. & $\begin{array}{l}\text { Dyspnea, drowsiness, fatigue. The effect occurs after the second } \\
\text { week. }\end{array}$ & {$[51,52]$} \\
\hline & $\begin{array}{l}\text { Antidepressants: Duloxetine, } \\
\text { Amitriptyline, Nortriptyline, } \\
\text { Venlafaxine }\end{array}$ & $\begin{array}{l}\text { Good effect against the neuropathic pain. Effects } \\
\text { similar to gabapentin and pregabalin. }\end{array}$ & Sleep disturbances, depression, and have muscarinic effects. & {$[46,47]$} \\
\hline & $\begin{array}{l}\text { Analgesics: Tapentadol, Tramadol, } \\
\text { Acetaminophen, Oxycodone }\end{array}$ & Reduce pain in diabetic polyneuropathy. & Confusion and sedation; opioids can be used inappropriately. & {$[11,46]$} \\
\hline & Alpha-lipoic acid & Delay or reverse damages to peripheral nerves. & There is no evidence evaluating long-term treatment. & [48] \\
\hline & Mesenchymal stem cells & $\begin{array}{l}\text { Neuroprotective effects. It can be easily isolated } \\
\text { from adipose tissue; has cell plasticity. }\end{array}$ & $\begin{array}{l}\text { The number of transplanted cells that reach and are integrated } \\
\text { into the functioning of the organ is low. The therapies are } \\
\text { expensive. }\end{array}$ & [49] \\
\hline & Interleukin 6 & Regenerates peripheral nerve fibers. & High doses can cause inflammation. & [50] \\
\hline \multirow[t]{5}{*}{$\begin{array}{l}\text { Ischemic Ulcer:(a) } \\
\text { Endovascular therapy }\end{array}$} & Angiosomas & $\begin{array}{l}\text { Increases arterial flow to the ischemic limb. } \\
\text { Get at least one pulsatile flow. } \\
\text { Improves the healing of ischemic ulcer. } \\
\text { Improves or eliminates pain at rest } \\
\text { Reduce the level of amputation. } \\
\text { Reduce the duration and number of } \\
\text { hospitalizations. } \\
\text { Improve mobility. } \\
\text { Improves quality of life. } \\
\text { Improves survival. }\end{array}$ & $\begin{array}{c}\text { Variability in infrapopliteal arterial distribution. } \\
\text { Differences between extension and borders of angiosomes. } \\
\text { Difficulties in identifying affected angiosoma. Many lesions } \\
\text { depend on several angiosomes. Objective diagnostic } \\
\text { angiographic pattern not described. } \\
\text { Optimal angiographic end point post endovascular therapy is } \\
\text { not known. Differences in collateralization. } \\
\text { Very long arterial segments. } \\
\text { Diffuse, calcified, and multiple lesions. } \\
\text { Small arterial caliber. } \\
\text { Slow flow of distal beds. } \\
\text { Poor run-off. } \\
\text { Instrument handling. } \\
\text { Technical difficulties. }\end{array}$ & [53-55] \\
\hline & Percutaneous transluminal angioplasty & $\begin{array}{l}\text { Technical feasibility reduces the number of } \\
\text { complications, and increases the rate of recovery } \\
\text { of the limb useful in elderly patient. }\end{array}$ & $\begin{array}{l}\text { Limited scientific evidence. } \\
\text { Not suitable for young patients. } \\
\text { Requires adjuvant treatment to prevent restenosis with platelet } \\
\text { inhibitors or vitamin antagonists K. }\end{array}$ & {$[55,56]$} \\
\hline & Stents & Improves blood flow. & $\begin{array}{l}\text { The permeability of the arteries after an angioplasty is the same } \\
\text { if this is placed than if it is omitted. }\end{array}$ & {$[57,58]$} \\
\hline & Angioplasty & $\begin{array}{l}\text { Increases the primary permeability of the vessel. } \\
\text { Revascularization of the target lesion. }\end{array}$ & $\begin{array}{l}\text { High percentage of restenosis. } \\
\text { Does not decrease the risk of amputation } \\
\text { High cost. }\end{array}$ & [59] \\
\hline & $\begin{array}{c}\text { Bypass: autologous } \\
\text { human umbilical vein and synthetic } \\
\text { materials with or without heparin }\end{array}$ & $\begin{array}{l}\text { Improve primary permeability. Preservation of } \\
\text { the foot. }\end{array}$ & Lack of scientific evidence. & {$[60,61]$} \\
\hline
\end{tabular}


Table 1. Cont

\begin{tabular}{|c|c|c|c|c|}
\hline Therapy for & Method & Advantage & Disadvantage & Reference \\
\hline \multirow{8}{*}{ (b) Anticoagulant Therapy } & $\begin{array}{l}\text { Plaquetary inhibitors. Antagonists of } \\
\text { vitamin K. }\end{array}$ & Adjuvant after angioplasty. & $\begin{array}{l}\text { Hemorrhages. } \\
\text { Hypersensitivity. } \\
\text { Gastrointestinal disorders. }\end{array}$ & [62] \\
\hline & Ginkgo biloba & Improves intermittent claudication. & Lack of scientific evidence. & [63] \\
\hline & Vitamin E & $\begin{array}{l}\text { Improves blood flow. } \\
\text { Increases the body's ability to repair. } \\
\text { No adverse effects. } \\
\text { Low cost. }\end{array}$ & Lack of documented scientific evidence. & [64] \\
\hline & Levocarnitine & $\begin{array}{l}\text { Improves walking tolerance. } \\
\text { Greater effectiveness intravenously. } \\
\text { Severe claudication better results. }\end{array}$ & $\begin{array}{l}\text { There are not enough studies documenting their effectiveness in } \\
\text { these patients. } \\
\text { No dose has been established, and duration of treatment for } \\
\text { patient safety. }\end{array}$ & {$[65,66]$} \\
\hline & Beta-blockers & $\begin{array}{l}\text { Its use does not affect walking distance, blood } \\
\text { flow, the vascular resistance of the leg, or skin } \\
\text { temperature. }\end{array}$ & Lack of scientific evidence. & [67] \\
\hline & Cilostazol & Improve walking distance. & $\begin{array}{l}\text { Presents mild and treatable side effects. } \\
\text { Lack of scientific evidence. }\end{array}$ & [68] \\
\hline & Hyperbaric oxygen therapy/ozone & $\begin{array}{l}\text { Improves symptoms. } \\
\text { Decreases ulcer area. } \\
\text { Shorter duration of hospitalization. }\end{array}$ & $\begin{array}{l}\text { The studies found are small, and there is a high risk of bias. } \\
\text { It requires adjuvants with antibiotics. }\end{array}$ & {$[69,70]$} \\
\hline & Stimulation of the spinal cord & $\begin{array}{l}\text { Decreased pain. } \\
\text { Greater limb preservation rate. } \\
\text { Regression of the ischemic limb state (Fontaine). } \\
\text { Improves the quality of life. }\end{array}$ & $\begin{array}{l}\text { High cost, the risk of complications, such as implantation } \\
\text { problems, infections that will eventually require reoperation. }\end{array}$ & {$[71,72]$} \\
\hline \multirow{2}{*}{ Infection } & Antibiotics & $\begin{array}{c}\text { Selective. } \\
\text { Low cost. } \\
\text { Mechanism of specific action. } \\
\text { Established doses. } \\
\text { Multiple administration routes. }\end{array}$ & $\begin{array}{l}\text { Drug interactions, high resistance potential } \\
\text { hypersensitivity. }\end{array}$ & [73] \\
\hline & Antimicrobial peptides of mammals & $\begin{array}{l}\text { Multiple mechanisms of action. } \\
\text { Broad-spectrum antimicrobial. } \\
\text { Low resistance potential. } \\
\text { Antiviral, antifungal, antibacterial, antitumor } \\
\text { activity. }\end{array}$ & $\begin{array}{l}\text { Its toxicity is unknown; it can only be administered topically. } \\
\text { Embryotoxic and paralyzing activity for sperm. } \\
\text { Short half-life, for the degradation of proteases, high price. }\end{array}$ & {$[73,74]$} \\
\hline
\end{tabular}




\subsection{Treatments for Peripheral Arterial Disease (Ischemia)}

Ischemia presenting in diabetic patients due to a reduction in blood flow that occurs in both small vessels (microvascular, such as capillaries) and large vessels (macrovascular, such as arteries and veins), or due to a decrease of angiogenesis, can be treated through revascularization of at least one of the foot arteries to try to restore blood flow in patients with a DFU whose toe pressure is $<30 \mathrm{mmHg}$ or transcutaneous oxygen pressure $(\mathrm{TcPO} 2)<25 \mathrm{mmHg}$, as well as in those who have a DFU that does not heal with pressure on the ankle of $<50 \mathrm{mmHg}$ or ankle-brachial index (ABI) $<0.5$ [75].

The revascularization techniques used as a first-line strategy are open bypass or endovascular techniques [76]. Bypass is usually more effective and ensures long patency in obstruction of the common femoral artery and its bifurcation or in the case of long occlusion of femoral-popliteal and infrapopliteal vessels; however, PAD may be treated by the endovascular approach in centers with a long experience of angioplasty [77]. Alternative techniques in the treatment of PAD are angioplasty in the lower extremities, in which a small balloon is passed into a narrow section of an artery, and inflated to open up the artery in order to improve blood flow. To be effective, this procedure must be performed on a permeable distal vessel [41,78]. Atherectomy is another technique, in which the atheroma is excised by a rotating cutting blade. However, there is no evidence for superiority of atherectomy over angioplasty on any outcome [77].

Once any of the aforementioned procedures is performed, the patient must receive multidisciplinary care to make the treatment effective. This includes pharmacological treatment for hypertension, hypercholesterolemia, and bleeding as a complication [79].

\subsection{Wound Dressings}

Clinical practice guidelines recommend the use of wound dressings to maintain a humid environment in the wound, help the absorption of exudate, prevent infections, and promote the healing of ulcers [80]. The standard dressings used in diabetic wounds are those that are not adherent, such as bandages [81]. However, specialized dressings are being developed, including hydrogels [82]. Zhao et al. reported that hydrogel with insulin and fibroblasts as bioactive dressings have promising potential in the treatment of DFUs, favoring neovascularization, collagen deposition, and wound healing [83]. Regarding hydrocolloid and foam dressings, no evidence has been found to suggest that these dressings are more effective than standard dressings [84].

\subsection{Debridement}

Debridement is a procedure where the necrotic tissue that is devitalized and the surrounding border of the DFU are removed and the healthy tissue is preserved [29], and is recommended at one to four weeks, depending on the progress of healing [80]. Among its objectives, control of the bacterial load allows early closure of the wound through conservative treatment or a skin graft.

Pressure over bone prominences can lead to callus formation, which represents a foreign body that can elevate the plantar pressure and predispose subcutaneous bleeding, causing the skin to break down and ulcer formation. Debridement of calluses often results in a significant reduction in foot pressure, facilitating accurate assessment and helping close the lesion [85]. In addition, debridement can allow health personnel to carry out an evaluation of the size, shape, and depth of the wound, as well as its characteristics for a better individualized treatment $[80,86]$. The appropriate technique for eliminating necrotic tissue is still a matter of debate [87].

\subsection{Relief of Pressure}

The constant and repetitive traumatism of the foot owing to inadequate footwear contributes to the development of a DFU [88]. For the relief of pressure, half-shoes, rigid-soled post-operative shoes, accommodative dressings, and total contact casts, either removable or immovable, are generally used in patients with ulcers of neuropathic origin. Their use has an impact factor in the relief of plantar 
pressure. Each case is individually assessed for classification and determination of the necessary time to produce ulcer healing; for example, in uncomplicated plantar ulcers, a period of 32-52 days is necessary to achieve a good result. The total contact cast has been shown to be $70 \%$ effective, and is it also used as the reference treatment by the American Diabetes Association [4]. Conventional or standard therapeutic footwear is not effective in healing the ulcer, owing to poor patient adherence to recommendations for using a removable device [89]; however, they are recommended because of their low cost and the possibilities they offer to generate an adequate discharge without causing alterations of greater severity in the ulcer [90]. They are contraindicated in patients with infection or osteomyelitis [91].

\subsection{Infection Treatment}

Antibiotic therapy for infected DFU will be empirical in the first instance, in accordance with the likely causative pathogen and the severity of the infection. The definitive treatment is modified according to the results obtained in the microbiological culture and the response of the empirical treatment. Its duration will depend on the severity of the infection; for example, a mild infection could remain for 1-2 weeks, or 2-4 weeks for a severe infection, or longer if there is osteomyelitis [23].

The recommended empiric antibiotic therapy according to severity is dicloxacillin, cephalexin, clindamycin, or amoxicillin/clavulanate for mild-moderate cases; vancomycin + ampicillin/sulbactam, moxifloxacin, cefoxitin, or cefotetan for moderate cases; and vancomycin + piperacillin/tazobactam, imipenem/cilastatin, meropenem, or doripenem for severe cases [92].

Several variables present in the infection of the wound, such as time of evolution, hygiene conditions, immune status of the host, polymicrobial infection, and previous treatment with antimicrobial agents, which can collaborate with the emergence of antimicrobial resistance [93]. Antimicrobial resistance may result in prolonged debility of the patient, changing the panorama and/or the index of the wound cure [94]. The most worrisome problem for infected DFUs is gram-negative organisms that produce beta-lactamase or carbapenems and even cause resistance to methylcycline with intermediate resistance to vancomycin [95].

\subsection{Antimicrobial Peptides}

Currently, the emergence and spread of bacteria resistant to conventional antibiotics is becoming a global threat. In this sense, alternative compounds are urgently needed. Antimicrobial peptides (AMPs) are molecules of the immune system of mammals whose function is to fight the invading pathogens [96]. AMPs are potent agents against a wide spectrum of pathogens, including viruses, fungi, and antibiotic-resistant bacteria, and have antitumor activities with a complex mechanism of action. They are able to target the cytoplasmic membrane and interfere with DNA and protein synthesis, protein folding, and cell wall synthesis, thus intervening in the immunomodulatory functions, including the inflammatory process and cicatrization [73]. Mammalian antimicrobial peptides can be found in the granules of neutrophils, epithelial cells of the skin, and mucous membranes, as well as in protein degradation products [97]. Their use as monotherapy in the treatment of infections, in combination with conventional antibiotics for synergistic purposes, immunomodulators, and neutralizing endotoxins, has been suggested [73]. In DFUs, several antimicrobial peptides have been assessed including nisin, $\alpha$-helical antimicrobial decapeptide KKVVFWVKFK (KSL-W), ubiquicidin 29-41 (UBI 29-41), pexiganan (MSI-78), and beta-defensin-2 (hBD2); however, only pexiganan (MSI-78) is in clinical phase development as a topical cream [98-103]. There are currently no peptides approved for use in humans by the Food and Drug Administration (FDA).

\subsection{Larval Therapy}

Larval therapy was introduced in 1940 in the United States and later abandoned after the appearance of antibiotics; however, since bacterial resistance was found, the therapy was reintroduced by the United Kingdom in the 1990s. It is still a little-used therapy, but it seems to be a promising 
technique in the treatment of hard-to-heal wounds [104]. The most-used maggots for the treatment of DFUs are Lucilia cuprina, a species of blow fly. The maggots are sterilized and placed directly on necrotic chronic wounds for evaluation of their efficacy of debridement. This procedure has been tested in diabetic patients and in different animal models of DFUs. The results showed that after treatment with several cycles of maggots, the wound was completely free of bacterial contamination and healed, and new tissues to close the wound were formed $[105,106]$.

\subsection{Laser Therapy}

Low-level laser therapy (LLLT) involves the use of light in the form of light emitting diodes of a low-level. This treatment is considered an effective therapeutic method in wound healing when certain factors are properly observed, such as power input, dosage, time, and interval between sessions. LLLT alters the cell function, and molecular and biochemical pathways, which may result in changes in cell shape, migration, and cell signaling. These changes promote the reduction of the inflammatory phase, favoring the angiogenesis and the production of extracellular matrix components, accelerating the healing process [107]. LLLT has the advantage of being easily administered, but is considered an emerging modality of high-cost treatment with limited results, based on previous studies [108].

\section{Tissue Engineering Approaches}

Tissue engineering is a field of regenerative medicine that refers to the practice of combining scaffolds, cells, and growth factors with the goal of restoring, maintaining, or improving damaged tissues or whole organs [109]. In the case of DFUs, new dressings designed with living tissues have been developed to function as a substitute for injured skin. It is believed that their mechanism of action is to fill the wound with cells and extracellular matrix, thus inducing the expression of growth factors and cytokines that contribute to wound healing [110].

\subsection{Growth Factors}

Growth factors are proteins that can stimulate and activate the process of cell proliferation through activating angiogenesis, the transcription of genes, and other reactions that favor the closure of wounds [111]. Experimental studies have helped to elucidate the function and effectiveness of individual cytokines and growth factors in DFU tissue repair. The most common include the following: epidermal growth factor (EGF), which acts in the stimulation of epidermal cells and increases the proliferation of fibroblasts to thereby increase the production of collagen at the site of the lesion [112,113]; platelet-derived growth factor (PDGF), which stimulates fibroblasts for the formation of epithelial tissue, although no effect has been found in keratinocytes [112]; fibroblast growth factor (FGF) and transforming growth factor beta (TGF- $\beta$ ), which are inducers of angiogenesis; vascular endothelial growth factor (VEGF), a potent mitogen for vascular endothelial cells that can also stimulate angiogenesis; and autologous platelet-rich plasma (PRP). These growth factors were assessed parenterally through their application (alone or loaded in a dressing matrix) on the surface of the ulcer, or infiltrated directly into the wound. They contribute to the healing of wounds caused by DFUs in DM type 1 and type 2 [114-116]. Regarding the use of growth factors in clinical trials, only EGF has been tested in patients with DFUs, showing high cure rates [117]. The use of the other growth factors is still not recommended owing to a lack of scientific evidence on the safety profile of the damage and benefits of their use.

\subsection{Cells}

Among the cell types used for wound repair are mesenchymal stem cells (MSCs), which possess the potential for multilineage differentiation into neurogenic, chondrogenic, adipogenic, osteogenic, myogenic, and endothelial cells in the presence of lineage-specific induction factors; they are relatively easy to obtain from different tissue sources and expand in culture [118]. Several studies have evaluated the regenerative potential of MSCs derived from bone marrow and umbilical cord blood, 
by administrating them intramuscularly, intra-arterially, and topically in diabetic patients with DFUs in clinical trials. The results showed that they can accelerate wound closure, ameliorate clinical parameters, and improve the healing of DFUs [119]. In spite of the promising results in preclinical studies, as well as their safety and efficacy in the treatment of DFUs, the appropriate cell type and selection between autologous or allogeneic MSCs are yet to be discussed. In the same way, MSCs derived from adipose tissue were investigated in combination with Exendin- 4 to evaluate their improvement effect on diabetic wound healing in a diabetic murine model. The results showed a rapid reduction in the size of the wound compared with controls [120]. A mechanism proposed for the healing effect of MSCs is their paracrine effect over both cell proliferation and the process of angiogenesis, as well as the regulation of local mRNA expression of some factors involved in healing [121].

In the same sense, fibroblasts and keratinocytes were evaluated alone or in combination as allografts or autografts to cover chronic ulcers for treatment of DFUs [122]. These cells are known to enhance wound healing by synthesizing several growth factors and major extracellular matrix components of the dermal and epidermal layers of the skin [123].

\subsection{Scaffolds}

The biomaterials currently used as matrices for wound repair can be classified according to their origin, either natural or synthetic. Among the natural matrices are collagen [56], hyaluronic acid [124], fibrin [125], chitosan [126], and alginate [127], which are recommended because of their easy degradation and high biocompatibility. Among the synthetic matrices are poly(acrylic acid) (PAA) [128], polyglycolic acid (PGA) [129], poly(lactic-co-glycolic acid) (PLGA) [130], poly(e-caprolactone) (PCL) [131], PCL-poly(ethylene glycol) (PEG) [132], gelatin methacrylate (GelMA) [133], and pluronic F-127 [134], which are recommended to give resistance to scaffolding material. The biomaterials mentioned above are used as hydrogels, bandages, foam, and films.

\subsection{Human Skin Substitutes}

The use of skin substitutes that combine growth factors, cells, and/or biomaterials as a treatment for DFUs has been widely suggested and accepted. There are a great variety of skin substitutes made through tissue engineering. The mechanism by which they help wound healing depends on their anatomical shape and the main components and biomaterials. Examples include the following: Dermagraf ${ }^{\circledR}$, which owes its effect to its components such as metabolically active fibroblasts, components of the ECM, and a bioabsorbable synthetic scaffold [135]; Apligraf ${ }^{\circledR}$, whose healing effect is the result of the production of cytokines and growth factors similar to healthy human skin [136]; Regranex $^{\circledR}$ (Becaplermin), which has biological activity similar to natural PDGF, and which has been shown to promote the formation of granulation tissue and aid wound healing [137]; and AlloDerm ${ }^{\circledR}$, which consists of an organized acellular dermal matrix of normal collagen, allowing new human skin to regenerate and causing neovascularization [138]. The main products of regenerative medicine available and their characteristics are summarized in Table 2.

Table 2. Description of human skin substitutes for the treatment of DFUs. FDA, Food and Drug Administration.

\begin{tabular}{ccc}
\hline Type of Product & Name/Clinical Phase & Composition \\
\hline Cell therapy & $\begin{array}{c}\text { Dermagraft/Approved by the } \\
\text { FDA. }\end{array}$ & $\begin{array}{c}\text { Dermal substitute derived from cryopreserved } \\
\text { human fibroblasts composed of fibroblasts, } \\
\text { extracellular matrix, and a bioabsorbable } \\
\text { scaffold [139]. }\end{array}$ \\
Cell therapy & Apligraf/Approved by the FDA in \\
1998. & $\begin{array}{c}\text { Two-layer skin substitute: the epidermal layer } \\
\text { is composed of human keratinocytes; the } \\
\text { dermal layer is formed by hum fibroblasts in } \\
\text { a type I bovine collagen matrix [140]. }\end{array}$ \\
\hline
\end{tabular}


Table 2. Cont.

\begin{tabular}{|c|c|c|}
\hline Type of Product & Name/Clinical Phase & Composition \\
\hline Cell therapy & $\begin{array}{c}\text { Becaplermin/Approved by the } \\
\text { FDA. }\end{array}$ & $\begin{array}{l}\text { Transparent colorless to straw-colored gel, } \\
\text { which contains } 0.01 \% \text { of the active } \\
\text { ingredient becaplermin [137]. }\end{array}$ \\
\hline Cell therapy & OrCel/Approved by the FDA. & $\begin{array}{l}\text { The cultivated skin compound is an } \\
\text { absorbable bilayer of cellular matrix, made } \\
\text { of bovine collagen, in which the dermal } \\
\text { cells have been cultivated [141]. }\end{array}$ \\
\hline Cell therapy & Epicel/Approved by the FDA. & $\begin{array}{l}\text { Autograft grew for deep or full-thickness } \\
\text { dermal treatment comprising a surface area } \\
\text { of greater than } 30 \% \text { [142]. }\end{array}$ \\
\hline Biosynthetic & Biobrane/Approved by the FDA. & $\begin{array}{l}\text { Biosynthetic dressing for wounds, } \\
\text { consisting of a single silicon film with a } \\
\text { nylon fabric partially embedded in the film. } \\
\text { The fabric creates a complex of the } \\
\text { three-dimensional structure of thread } \\
\text { trifilamento, which chemically binds to the } \\
\text { collagen. The blood and serum form a clot } \\
\text { in the nylon matrix of the dressing that } \\
\text { adheres to the wound until epithelization } \\
\text { occurs [143]. }\end{array}$ \\
\hline Biosynthetic & Integra/Approved by the FDA. & $\begin{array}{l}\text { A compound of bovine collagen with } \\
\text { dermal glycosaminoglycans coated with a } \\
\text { silicone, as a temporary epidermal } \\
\text { substitute [144]. }\end{array}$ \\
\hline Biosynthetic & $\begin{array}{c}\text { TansCyte/Approved by the FDA in } \\
1997 .\end{array}$ & $\begin{array}{l}\text { Human dermal fibroblasts cultured in a } \\
\text { nylon mesh, combined with a synthetic } \\
\text { epidermal layer. Used as a temporary cover } \\
\text { for some wounds that heal without } \\
\text { autografting [145]. }\end{array}$ \\
\hline Collagen Support & OASIS/Approved by the FDA. & $\begin{array}{l}\text { Support of xenogenic collagen derived from } \\
\text { the porcine intestinal mucosa [146]. }\end{array}$ \\
\hline Acellular Dermal Matrix & AlloDerm/Approved by the FDA. & $\begin{array}{l}\text { Acellular dermal matrix dressing (allograft), } \\
\text { used as a replacement tissue. The product is } \\
\text { created from the native human skin and } \\
\text { processed so that the basement membrane } \\
\text { and the cellular matrix remain intact [147]. }\end{array}$ \\
\hline Acellular Dermal Matrix & DermaMatrix/Unknown & $\begin{array}{l}\text { Acellular dermal matrix (allograft) from } \\
\text { donated human skin tissues; processed by } \\
\text { the skeletal muscle [148]. }\end{array}$ \\
\hline Acellular Dermal Matrix & GraftJacket/Approved by the FDA. & $\begin{array}{l}\text { Formed by a matrix of acellular } \\
\text { regenerative tissue that has been processed } \\
\text { from the donation of human skin; } \\
\text { minimally processed to eliminate epidermal } \\
\text { and dermal cells, while preserving the skin } \\
\text { structure at the same time [149]. }\end{array}$ \\
\hline
\end{tabular}

All these products help repair the skin and their main advantages include the ability to be supplemented with growth factors and drugs, such as antibiotics and anti-inflammatories, in order to achieve adequate wound healing. However, the cost associated with some devices must be considered [150]. These products act on different layers of the skin because they are developed based on different principles, origin, and anatomy; Figure 2 shows how these products are constituted. 


\section{Human Skin Substitutes}

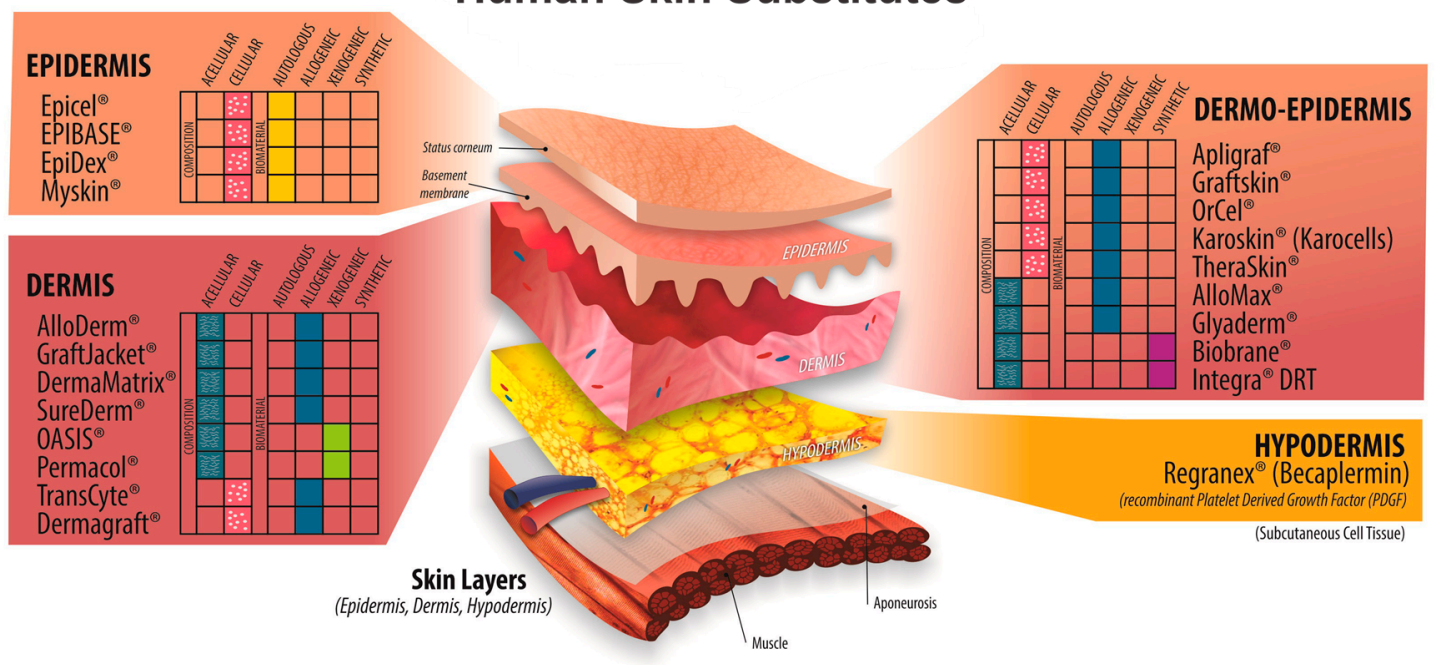

Figure 2. Human skin substitutes. Regenerative medicine products are based on different principles and components: some are integrated with cells, such as Dermagraf ${ }^{\circledR}$, Epicel ${ }^{\circledR}$, EpiDex $^{\circledR}$, EPIBASE, Myskin ${ }^{\circledR}$, TransCyte ${ }^{\circledR}$, Apligraf ${ }^{\circledR}$, Graftskin, OrCel ${ }^{\circledR}$, Karoskin $^{\circledR}$, and TheraSkin ${ }^{\circledR}$; others are acellular, such as AlloDerm ${ }^{\circledR}$, GraftJacket ${ }^{\circledR}$, DermaMatrix ${ }^{\circledR}$, OASIS $^{\circledR}$, SureDerm ${ }^{\circledR}$, Permacol $^{\circledR}$, AlloMax $^{\circledR}$, Glyaderm $^{\circledR}$, Biobrane ${ }^{\circledR}$, and Integra ${ }^{\circledR}$. The figure also outlines how these products have different anatomical origins, including the epidermis, such as Epice ${ }^{\circledR}$, EpiDex ${ }^{\circledR}$, EPIBASE, and Myskin ${ }^{\circledR}$; the dermis, such as AlloDerm ${ }^{\circledR}$, GraftJacket ${ }^{\circledR}$, DermaMatrix ${ }^{\circledR}$, OASIS $^{\circledR}$, SureDerm ${ }^{\circledR}$, Permacol ${ }^{\circledR}$, TransCyte ${ }^{\circledR}$, and Dermagraf ${ }^{\circledR}$; dermo-epidemics, such as Apligraf ${ }^{\circledR}$, Graftskin, OrCel ${ }^{\circledR}$, $\operatorname{Karoskin}^{\circledR}$, TheraSkin ${ }^{\circledR}$, AlloMax ${ }^{\circledR}$, Glyaderm ${ }^{\circledR}$, Biobrane ${ }^{\circledR}$, and Integra ${ }^{\circledR}$; and the hypodermis, such as Regranex ${ }^{\circledR}$ (Becaplermin).

\section{Conclusions}

DFUs precede $85 \%$ of lower extremity amputations. They often lead to complications such as infection, osteomyelitis, and abscesses. DFUs greatly impact physical, psychological, social, and economic aspects for patients, affecting their quality of life. Management of DFUs requires the correct classification of stage and severity. Adequate care for DFUs should include a focus on DM control as well as on wound care, proper infection control, relieving pressure, and optimizing blood flow. The basic care for the control and treatment of DFUs includes discharge, debridement processes, revascularization, and antibiotic therapy. Therapeutic footwear reduces ulcer recurrence, although few studies are available that have assessed its efficacy and the prevention of initial ulceration. Several methods of debridement (including the use of larvae) and revascularization have been used to improve the healing process of ischemic ulcers. They have been shown to be effective in reducing pain and increasing arterial flow to the ischemic limb, as well as reducing the risk of amputation. However, more studies are needed to determine the patient populations for which these therapies are helpful, as well as their cost-to-benefit ratios. AMPs are potent agents against a wide spectrum of pathogens, including viruses, fungi, and antibiotic-resistant bacteria, and have antitumor activity, which represents an alternative treatment to conventional antibiotic therapy.

With technological advancement, a number of biological healing products have been developed to aid in the healing process of DFUs. Tissue engineering represents a novel treatment for DFUs, including the use of dressings for wounds designed with living tissues to function as skin substitutes. These skin substitutes use living cells such as fibroblasts, keratinocytes, and stem cells, alone or in combination with extracellular matrices, and growth factors. Even though the use of these new therapies is expensive, they are supported by several clinical trials, encouraging their use, and representing potential new therapies for the future. 
Author Contributions: All authors participated in the conceptualization, resources, writing-review and editing. A.P.-F., M.L.M.-F., J.G.R.-L., and I.G.-V. contributed to writing-original draft preparation; M.L.M.-F. and I.G.-V. participated in funding acquisition.

Funding: This study was funded in part by the CONACyT: PDCPN- 2015-01-63, INFR-2014-01-225520, INFR-2015-01-254106, SEP-CONACYT-CB-2015-258316, SS/IMSS/ISSSTE-CONACYT-2016-01-273144, and SALUD-FOSSIS-S0008-2016-02-273142. The Academic Unit of Human Medicine and Health Sciences-UAZ provided the publication financing.

Acknowledgments: Aurelio Perez-Favila wants to thank the CONACyT master's degree scholarship, with scholarship holder number 607455.

Conflicts of Interest: The authors declare no conflict of interest.

\section{References}

1. American Diabetes Association. Diagnosis and classification of diabetes mellitus. Diabetes Care 2009, 32 (Suppl. 1), S62-S67. [CrossRef] [PubMed]

2. International Diabetes Federation. IDF Diabetes Atlas; International Diabetes Federation: Brussels, Belgium, 2017; p. 150.

3. Goday, A. Epidemiology of diabetes and its non-coronary complications. Rev. Esp. Cardiol. 2002, 55, 657-670. [CrossRef]

4. Lozano-Platonoff, A.; Mejía-Mendoza, M.D.F.; Ibáñez-Doria, M.; Contreras-Ruiz, J. The gold standard in diabetic foot treatment: Total contact cast. Gac. Med. Mex. 2014, 150, 58-64. [PubMed]

5. Dubsky, M.; Jirkovska, A.; Bem, R.; Fejfarova, V.; Skibova, J.; Schaper, N.C.; Lipsky, B.A. Risk factors for recurrence of diabetic foot ulcers: prospective follow-up analysis in the Eurodiale subgroup. Int. Wound J. 2013, 10, 555-561. [CrossRef]

6. Buowari, O.Y. Diabetes Mellitus in Developing Countries and Case Series, in Diabetes Mellitus-Insights and Perspectives; Oguntibeju, O.O., Ed.; IntechOpen: London, UK, 2013; p. 19.

7. Ren, M.; Yang, C.; Lin, D.Z.; Xiao, H.S.; Mai, L.F.; Guo, Y.C.; Yan, L. Effect of intensive nursing education on the prevention of diabetic foot ulceration among patients with high-risk diabetic foot: a follow-up analysis. Diabetes Technol. Ther. 2014, 16, 576-581. [CrossRef]

8. Boulton, A.J. The Pathway to Foot Ulceration in diabetes. Med. Clin. N. Am. 2013, 97, 775-790. [CrossRef]

9. Alavi, A.; Sibbald, R.G.; Mayer, D.; Goodman, L.; Botros, M.; Armstrong, D.G.; Woo, K.; Boeni, T.; Ayello, E.A.; Kirsner, R.S. Diabetic foot ulcers: Part I. Pathophysiology and prevention. J. Am. Acad. Dermatol. 2014, 70, 1 e1-1 e18. [CrossRef]

10. Boulton, A.J.; Gries, F.A.; Jervell, J.A. Guidelines for the diagnosis and outpatient management of diabetic peripheral neuropathy. Diabet. Med. 1998, 15, 508-514. [CrossRef]

11. Watson, J.C.; Dyck, P.J. Peripheral Neuropathy: A Practical Approach to Diagnosis and Symptom Management. Mayo Clin. Proc. 2015, 90, 940-951. [CrossRef]

12. Lavery, L.A.; Higgins, K.R.; Lanctot, D.R.; Constantinides, G.P.; Zamorano, R.G.; Athanasiou, K.A.; Armstrong, D.G.; Agrawal, C.M. Preventing diabetic foot ulcer recurrence in high-risk patients: use of temperature monitoring as a self-assessment tool. Diabetes Care 2007, 30, 14-20. [CrossRef]

13. Forsythe, R.O.; Brownrigg, J.; Hinchliffe, R.J. Peripheral arterial disease and revascularization of the diabetic foot. Diabetes Obes. Metab. 2015, 17, 435-444. [CrossRef] [PubMed]

14. Dinh, T.L.; Veves, A. A review of the mechanisms implicated in the pathogenesis of the diabetic foot. Int. J. Low Extrem. Wounds 2005, 4, 154-159. [CrossRef] [PubMed]

15. Lanzer, P. Primary media sclerosis Mönckeberg: Diagnostic criteria. Cor Vasa 2017, 60, e205-e208. [CrossRef]

16. Glagov, S.; Weisenberg, E.; Zarins, C.K.; Stankunavicius, R.; Kolettis, G.J. Compensatory enlargement of human atherosclerotic coronary arteries. N. Engl. J. Med. 1987, 316, 1371-1375. [CrossRef] [PubMed]

17. Geerlings, S.E.; Hoepelman, A.I. Immune dysfunction in patients with diabetes mellitus (DM). FEMS Immunol. Med. Microbiol. 1999, 26, 259-265. [CrossRef] [PubMed]

18. Moutschen, M.P.; Scheen, A.J.; Lefebvre, P.J. Impaired immune responses in diabetes mellitus: Analysis of the factors and mechanisms involved. Relevance to the increased susceptibility of diabetic patients to specific infections. Diabete Metab. 1992, 18, 187-201. [PubMed] 
19. Fejfarova, V.; Jirkovska, A.; Dubsky, M.; Game, F.; Vydlakova, J.; Sekerkova, A.; Franekova, J.; Kucerova, M.; Striz, I.; Petkov, V.; et al. An Alteration of Lymphocytes Subpopulations and Immunoglobulins Levels in Patients with Diabetic Foot Ulcers Infected Particularly by Resistant Pathogens. J. Diabetes Res. 2016, 2016, 2356870. [CrossRef]

20. Lipsky, B.A.; Berendt, A.R.; Deery, H.G.; Embil, J.M.; Joseph, W.S.; Karchmer, A.W.; LeFrock, J.L.; Lew, D.P.; Mader, J.T.; Norden, C.; et al. Diagnosis and treatment of diabetic foot infections. Clin. Infect. Dis. 2004, 39, 885-910. [CrossRef]

21. Mendes, J.J.; Leandro, C.; Corte-Real, S.; Barbosa, R.; Cavaco-Silva, P.; Melo-Cristino, J.; Gorski, A.; Garcia, M. Wound healing potential of topical bacteriophage therapy on diabetic cutaneous wounds. Wound Repair. Regen. 2013, 21, 595-603. [CrossRef]

22. Mendes, J.J.; Leandro, C.I.; Bonaparte, D.P.; Pinto, A.L. A rat model of diabetic wound infection for the evaluation of topical antimicrobial therapies. Comp. Med. 2012, 62, 37-48.

23. Grigoropoulou, P.; Eleftheriadou, I.; Jude, E.B.; Tentolouris, N. Diabetic Foot Infections: An Update in Diagnosis and Management. Curr. Diabetes Rep. 2017, 17, 3. [CrossRef] [PubMed]

24. Nelson, E.A.; O’Meara, S.; Craig, D.; Iglesias, C.; Golder, S.; Dalton, J.; Claxton, K.; Bell-Syer, S.E.; Jude, E.; Dowson, C.; et al. A series of systematic reviews to inform a decision analysis for sampling and treating infected diabetic foot ulcers. Health Technol. Assess. 2006, 10, 1-221. [CrossRef]

25. Moffarah, A.S.; Al Mohajer, M.; Hurwitz, B.L.; Armstrong, D.G. Diagnostic microbiology of the immunocompromised host: skin and soft tissue infection. Microbiol Spectrum. 2016, 4, 1-17.

26. Rahim, K.; Saleha, S.; Zhu, X.; Huo, L.; Basit, A.; Franco, O.L. Bacterial Contribution in Chronicity of Wounds. Microb. Ecol. 2017, 73, 710-721. [CrossRef] [PubMed]

27. Santoro, M.M.; Gaudino, G. Cellular and molecular facets of keratinocyte reepithelization during wound healing. Exp. Cell Res. 2005, 304, 274-286. [CrossRef]

28. Erem, C.; Hacihasanoglu, A.; Celik, S.; Ovali, E.; Ersoz, H.O.; Ukinc, K.; Deger, O.; Telatar, M. Coagulation and fibrinolysis parameters in type 2 diabetic patients with and without diabetic vascular complications. Med. Princ. Pract. 2005, 14, 22-30. [CrossRef]

29. Chhabra, S.; Chhabra, N.; Kaur, A.; Gupta, N. Wound Healing Concepts in Clinical Practice of OMFS. J. Maxillofac. Oral Surg. 2017, 16, 403-423. [CrossRef]

30. Werner, S.; Grose, R. Regulation of wound healing by growth factors and cytokines. Physiol. Rev. 2003, 83, 835-870. [CrossRef]

31. Xiao, J.; Li, J.; Cai, L.; Chakrabarti, S.; Li, X. Cytokines and diabetes research. J. Diabetes Res. 2014, 2014, 920613. [CrossRef]

32. Pradhan, L.; Nabzdyk, C.; Andersen, N.D.; LoGerfo, F.W.; Veves, A. Inflammation and neuropeptides: The connection in diabetic wound healing. Expert Rev. Mol. Med. 2009, 11, e2. [CrossRef]

33. Falanga, V. Wound healing and its impairment in the diabetic foot. Lancet 2005, 366, 1736-1743. [CrossRef]

34. Lan, C.C.; Liu, I.H.; Fang, A.H.; Wen, C.H.; Wu, C.S. Hyperglycaemic conditions decrease cultured keratinocyte mobility: Implications for impaired wound healing in patients with diabetes. Br. J. Dermatol. 2008, 159, 1103-1115. [CrossRef] [PubMed]

35. Galiano, R.D.; Tepper, O.M.; Pelo, C.R.; Bhatt, K.A.; Callaghan, M.; Bastidas, N.; Bunting, S.; Steinmetz, H.G.; Gurtner, G.C. Topical vascular endothelial growth factor accelerates diabetic wound healing through increased angiogenesis and by mobilizing and recruiting bone marrow-derived cells. Am. J. Pathol. 2004, 164, 1935-1947. [CrossRef]

36. Lobmann, R.; Schultz, G.; Lehnert, H. Proteases and the diabetic foot syndrome: Mechanisms and therapeutic implications. Diabetes Care 2005, 28, 461-471. [CrossRef] [PubMed]

37. Maione, A.G.; Smith, A.; Kashpur, O.; Yanez, V.; Knight, E.; Mooney, D.J.; Veves, A.; Tomic-Canic, M.; Garlick, J.A. Altered ECM deposition by diabetic foot ulcer-derived fibroblasts implicates fibronectin in chronic wound repair. Wound Repair Regen. 2016, 24, 630-643. [CrossRef]

38. Wang, C.; Mai, L.; Yang, C.; Liu, D.; Sun, K.; Song, W.; Luo, B.; Li, Y.; Xu, M.; Zhang, S.; et al. Reducing major lower extremity amputations after the introduction of a multidisciplinary team in patient with diabetes foot ulcer. BMC Endocr. Disord. 2016, 16, 38. [CrossRef]

39. Blakely, M. The Use of Best Practice in the Treatment of a Complex Diabetic Foot Ulcer: A Case Report. Healthcare (Basel) 2016, 4, 18. [CrossRef] 
40. Wu, S.C.; Wu, S.C.; Driver, V.R.; Wrobel, J.S.; Armstrong, D.G. Foot ulcers in the diabetic patient, prevention and treatment. Vasc. Health Risk Manag. 2007, 3, 65-76.

41. Brem, H.; Sheehan, P.; Boulton, A.J. Protocol for treatment of diabetic foot ulcers. Am. J. Surg. 2004, 187, 1S-10S. [CrossRef]

42. Markakis, K.; Bowling, F.L.; Boulton, A.J. The diabetic foot in 2015: An overview. Diabetes Metab. Res. Rev. 2016, 32, 169-178. [CrossRef]

43. Tang, H.Y.; Jiang, A.J.; Ma, J.L.; Wang, F.J.; Shen, G.M. Understanding the Signaling Pathways Related to the Mechanism and Treatment of Diabetic Peripheral Neuropathy. Endocrinology. 2019, 160, 2119-2127. [CrossRef] [PubMed]

44. Kennedy, W.R.; Navarro, X.; Goetz, F.C.; Sutherland, D.E.; Najarian, J.S. Effects of pancreatic transplantation on diabetic neuropathy. N. Engl. J. Med. 1990, 322, 1031-1037. [CrossRef] [PubMed]

45. Games, G.; Hutchison, A. Tapentadol-ER for the treatment of diabetic peripheral neuropathy. Consult. Pharm. 2013, 28, 672-675. [CrossRef] [PubMed]

46. Attal, N.; Cruccu, G.; Baron, R.; Haanpaa, M.; Hansson, P.; Jensen, T.S.; Nurmikko, T. EFNS guidelines on the pharmacological treatment of neuropathic pain: 2010 revision. Eur. J. Neurol. 2010, 17, 1113-e88. [CrossRef] [PubMed]

47. Javed, S.; Alam, U.; Malik, R.A. Burning through the pain: Treatments for diabetic neuropathy. Diabetes Obes. Metab. 2015, 17, 1115-1125. [CrossRef]

48. Bartkoski, S.; Day, M. Alpha-Lipoic Acid for Treatment of Diabetic Peripheral Neuropathy. Am. Fam. Physician 2016, 93, 786.

49. Oses, C.; Olivares, B.; Ezquer, M.; Acosta, C.; Bosch, P.; Donoso, M.; Leniz, P.; Ezquer, F. Preconditioning of adipose tissue-derived mesenchymal stem cells with deferoxamine increases the production of pro-angiogenic, neuroprotective and anti-inflammatory factors: Potential application in the treatment of diabetic neuropathy. PLoS ONE 2017, 12, e0178011. [CrossRef]

50. Cox, A.A.; Sagot, Y.; Hedou, G.; Grek, C.; Wilkes, T.; Vinik, A.I.; Ghatnekar, G. Low-Dose Pulsatile Interleukin-6 As a Treatment Option for Diabetic Peripheral Neuropathy. Front. Endocrinol. (Lausanne) 2017, 8, 89. [CrossRef]

51. Dworkin, R.H.; O’Connor, A.B.; Backonja, M.; Farrar, J.T.; Finnerup, N.B.; Jensen, T.S.; Kalso, E.A.; Loeser, J.D.; Miaskowski, C.; Nurmikko, T.J.; et al. Pharmacologic management of neuropathic pain: Evidence-based recommendations. Pain 2007, 132, 237-251. [CrossRef]

52. Raskin, P.; Huffman, C.; Yurkewicz, L.; Pauer, L.; Scavone, J.M.; Yang, R.; Parsons, B. Pregabalin in Patients With Painful Diabetic Peripheral Neuropathy Using an NSAID for Other Pain Conditions: A Double-Blind Crossover Study. Clin. J. Pain 2016, 32, 203-210. [CrossRef]

53. Fernández-Samos Gutiérrez, R. The angiosome model in the revascularization strategy of critical limb ischemia. Angiología 2012, 64, 173-182. [CrossRef]

54. Taylor, S.M.; Johnson, B.L.; Samies, N.L.; Rawlinson, R.D.; Williamson, L.E.; Davis, S.A.; Kotrady, J.A.; York, J.W.; Langan, E.M., 3rd.; Cull, D.L. Contemporary management of diabetic neuropathic foot ulceration: A study of 917 consecutively treated limbs. J. Am. Coll. Surg. 2011, 212, 532-545. [CrossRef] [PubMed]

55. Iida, O.; Soga, Y.; Hirano, K.; Kawasaki, D.; Suzuki, K.; Miyashita, Y.; Terashi, H.; Uematsu, M. Long-term results of direct and indirect endovascular revascularization based on the angiosome concept in patients with critical limb ischemia presenting with isolated below-the-knee lesions. J. Vasc. Surg. 2012, 55, 363-370. [CrossRef]

56. Lee, V.; Singh, G.; Trasatti, J.P.; Bjornsson, C.; Xu, X.; Tran, T.N.; Yoo, S.S.; Dai, G.; Karande, P. Design and fabrication of human skin by three-dimensional bioprinting. Tissue Eng. Part C Methods 2014, 20, 473-484. [CrossRef] [PubMed]

57. Bachoo, P.; et al. Endovascular stents for intermittent claudication. Cochrane Database Syst. Rev. 2010, CD003228. [CrossRef]

58. Bavishi, C.; Baber, U.; Panwar, S.; Pirrotta, S.; Dangas, G.D.; Moreno, P.; Tamis-Holland, J.; Kini, A.S.; Sharma, S.K. Efficacy and safety of everolimus and zotarolimus-eluting stents versus first-generation drug-eluting stents in patients with diabetes: A meta-analysis of randomized trials. Int. J. Cardiol. 2017, 230, 310-318. [CrossRef] 
59. Kayssi, A.; Al-Atassi, T.; Oreopoulos, G.; Roche-Nagle, G.; Tan, K.T.; Rajan, D.K. Drug-eluting balloon angioplasty versus uncoated balloon angioplasty for peripheral arterial disease of the lower limbs. Cochrane Database Syst. Rev. 2016, CD011319. [CrossRef]

60. Ambler, G.K.; Twine, C.P. Graft type for femoro-popliteal bypass surgery. Cochrane Database Syst Rev. 2018, 2, 1-113. [CrossRef]

61. Albers, M.; Romiti, M.; Brochado-Neto, F.C.; Pereira, C.A.B. Meta-analysis of alternate autologous vein bypass grafts to infrapopliteal arteries. J. Vasc. Surg. 2005, 42, 449-455. [CrossRef]

62. Palomo, I.; Moore-Carrasco, R.E.; Alarcón, M.A.; Maragaño, P.J. Platelet antiaggregants: Mechanisms of action and use asocied risks. Vitae Revista Facultad de Química Farmacéutica 2008, 16, 133-143.

63. Nicolai, S.P.; Kruidenier, L.M.; Bendermacher, B.L.; Prins, M.H.; Stokmans, R.A.; Broos, P.P.; Teijink, J.A. Ginkgo biloba for intermittent claudication. Cochrane Database Syst. Rev. 2013, CD006888. [CrossRef] [PubMed]

64. Kleijnen, J.; Mackerras, D. Vitamin E for intermittent claudication. Cochrane Database Syst. Rev. 2000, 2, 1-13. [CrossRef] [PubMed]

65. Brass, E.P.; Koster, D.; Hiatt, W.R.; Amato, A. A systematic review and meta-analysis of propionyl-L-carnitine effects on exercise performance in patients with claudication. Vasc. Med. 2013, 18, 3-12. [CrossRef] [PubMed]

66. Delaney, C.L.; Spark, J.I.; Thomas, J.; Wong, Y.T.; Chan, L.T.; Miller, M.D. A systematic review to evaluate the effectiveness of carnitine supplementation in improving walking performance among individuals with intermittent claudication. Atherosclerosis 2013, 229, 1-9. [CrossRef]

67. Paravastu, S.C.; Mendonca, D.A.; Da Silva, A. Beta blockers for peripheral arterial disease. Cochrane Database Syst. Rev. 2013, CD005508. [CrossRef]

68. Bedenis, R.; Stewart, M.; Cleanthis, M.; Robless, P.; Mikhailidis, D.P.; Stansby, G. Cilostazol for intermittent claudication. Cochrane Database Syst. Rev. 2014, CD003748. [CrossRef]

69. Lauvrak, V.; Fronsdal, K.B.; Ormstad, S.S.; Vaagbo, G.; Fure, B. Effectiveness of Hyperbaric Oxygen Therapy in Patients with Late Radiation Tissue Injury or Diabetic Foot Ulcer; The Norwegian Institute of Public Health: Oslo, Norway, 2015.

70. Liu, J.; Zhang, P.; Tian, J.; Li, L.; Li, J.; Tian, J.H.; Yang, K. Ozone therapy for treating foot ulcers in people with diabetes. Cochrane Database Syst. Rev. 2015, CD008474. [CrossRef]

71. Ubbink, D.T.; Vermeulen, H. Spinal cord stimulation for non-reconstructable chronic critical leg ischaemia. Cochrane Database Syst. Rev. 2013, CD004001. [CrossRef]

72. Simpson, E.L.; Duenas, A.; Holmes, M.W.; Papaioannou, D.; Chilcott, J. Spinal cord stimulation for chronic pain of neuropathic or ischaemic origin: systematic review and economic evaluation. Health Technol. Assess. 2009, 13, 1-154. [CrossRef]

73. Germán AlbertoTéllez, J.C. Péptidos antimicrobianos-Antimicrobial peptides. Infectio 2010, 14, 55-67.

74. Gomes, A.; Teixeira, C.; Ferraz, R.; Prudencio, C.; Gomes, P. Wound-Healing Peptides for Treatment of Chronic Diabetic Foot Ulcers and Other Infected Skin Injuries. Molecules 2017, 22, 1743. [CrossRef] [PubMed]

75. Hinchliffe, R.J.; Brownrigg, J.R.; Apelqvist, J.; Boyko, E.J.; Fitridge, R.; Mills, J.L.; Reekers, J.; Shearman, C.P.; Zierler, R.E.; Schaper, N.C.; et al. IWGDF guidance on the diagnosis, prognosis and management of peripheral artery disease in patients with foot ulcers in diabetes. Diabetes Metab. Res. Rev. 2016, 32, 37-44. [CrossRef] [PubMed]

76. Hinchliffe, R.J.; Brownrigg, J.R.; Andros, G.; Apelqvist, J.; Boyko, E.J.; Fitridge, R.; Mills, J.L.; Reekers, J.; Shearman, C.P.; Zierler, R.E.; et al. Effectiveness of revascularization of the ulcerated foot in patients with diabetes and peripheral artery disease: a systematic review. Diabetes Metab. Res. Rev. 2016, 32, 136-144. [CrossRef] [PubMed]

77. Uccioli, L.; Meloni, M.; Izzo, V.; Giurato, L.; Merolla, S.; Gandini, R. Critical limb ischemia: Current challenges and future prospects. Vasc. Health Risk Manag. 2018, 14, 63-74. [CrossRef]

78. Pomposelli, F.B., Jr.; et al. Dorsalis pedis arterial bypass: Durable limb salvage for foot ischemia in patients with diabetes mellitus. J. Vasc. Surg. 1995, 21, 375-384. [CrossRef]

79. Gatti, C.; Cecchini, S.; Fabbietti, P.; Romagnoli, F.; Ricci, S. Endovascular treatment of diabetic peripheral arterial disease in older and oldest old patients: A retrospective study. Aging Clin. Exp. Res. 2017, 30, 205-207. [CrossRef] 
80. Hingorani, A.; LaMuraglia, G.M.; Henke, P.; Meissner, M.H.; Loretz, L.; Zinszer, K.M.; Driver, V.R.; Frykberg, R.; Carman, T.L.; Marston, W.; et al. The management of diabetic foot: A clinical practice guideline by the Society for Vascular Surgery in collaboration with the American Podiatric Medical Association and the Society for Vascular Medicine. J. Vasc. Surg. 2016, 63, 3S-21S. [CrossRef]

81. Steed, D.L.; Attinger, C.; Colaizzi, T.; Crossland, M.; Franz, M.; Harkless, L.; Johnson, A.; Moosa, H.; Robson, M.; Serena, T.; et al. Guidelines for the treatment of diabetic ulcers. Wound Repair Regen. 2006, 14, 680-692. [CrossRef]

82. Dumville, J.C.; O’Meara, S.; Deshpande, S.; Speak, K. Hydrogel dressings for healing diabetic foot ulcers. Cochrane Database Syst Rev. 2013, 7, 1-54. [CrossRef]

83. Zhao, L.; Niu, L.; Liang, H.; Tan, H.; Liu, C.; Zhu, F. pH and Glucose Dual-Responsive Injectable Hydrogels with Insulin and Fibroblasts as Bioactive Dressings for Diabetic Wound Healing. ACS Appl. Mater. Interfaces 2017, 9, 37563-37574. [CrossRef]

84. Dumville, J.C.; Deshpande, S.; O’Meara, S.; Speak, K. Hydrocolloid dressings for healing diabetic foot ulcers. Cochrane Database Syst Rev. 2013, 8, 1-43. [CrossRef] [PubMed]

85. Registered Nurses' Association of Ontario. Assessment and Management of Foot Ulcers for People with Diabetes, 2nd ed.; Registered Nurses' Association of Ontario: Toronto, ON, Canada, 2013; Volume 1, 160 p.

86. Abouaesha, F.; van Schie, C.H.; Griffths, G.D.; Young, R.J.; Boulton, A.J. Plantar tissue thickness is related to peak plantar pressure in the high-risk diabetic foot. Diabetes Care 2001, 24, 1270-1274. [CrossRef] [PubMed]

87. Hirche, C.; Citterio, A.; Hoeksema, H.; Koller, J.; Lehner, M.; Martinez, J.R.; Monstrey, S.; Murray, A.; Plock, J.A.; Sander, F.; et al. Eschar removal by bromelain based enzymatic debridement (Nexobrid(R)) in burns: An European consensus. Burns 2017, 43, 1640-1653. [CrossRef] [PubMed]

88. Frykberg, R.G.; Zgonis, T.; Armstrong, D.G.; Driver, V.R.; Giurini, J.M.; Kravitz, S.R.; Landsman, A.S.; Lavery, L.A.; Moore, J.C.; Schuberth, J.M.; et al. Diabetic foot disorders. A clinical practice guideline (2006 revision). J. Foot Ankle Surg. 2006, 45, S1-S66. [CrossRef]

89. Fleischli, J.G.; Lavery, L.A.; Vela, S.A.; Ashry, H.; Lavery, D.C. 1997 William J. Stickel Bronze Award. Comparison of strategies for reducing pressure at the site of neuropathic ulcers. J. Am. Podiatr. Med. Assoc. 1997, 87, 466-472. [CrossRef] [PubMed]

90. Piaggesi, A.; Goretti, C.; Iacopi, E.; Clerici, G.; Romagnoli, F.; Toscanella, F.; Vermigli, C. Comparison of Removable and Irremovable Walking Boot to Total Contact Casting in Offloading the Neuropathic Diabetic Foot Ulceration. Foot Ankle Int. 2016, 37, 855-861. [CrossRef]

91. Health Quality Ontario. Fibreglass Total Contact Casting, Removable Cast Walkers, and Irremovable Cast Walkers to Treat Diabetic Neuropathic Foot Ulcers: A Health Technology Assessment. Ont. Health Technol. Assess. Ser. 2017, 17, 1-124.

92. Bergman, S.; Shah, P.J. Diabetic Foot Infections. In Infection Primary Care; Fish, D.N., Taylor, S., Thoennes, M.J., Eds.; Army Center for Substance Abuse Programs: Fort Knox, KY, USA, 2016; p. 26.

93. Singh, S.K.; Gupta, B. Choices and Challenges of Antibiotics Therapy in Diabetic Foot Infection. Indian J. Endocrinol. Metab. 2017, 21, 647-648.

94. Filius, P.M.; Gyssens, I.C. Impact of increasing antimicrobial resistance on wound management. Am. J. Clin. Dermatol. 2002, 3, 1-7. [CrossRef]

95. Meletis, G. Carbapenem resistance: Overview of the problem and future perspectives. Ther. Adv. Infect. Dis. 2016, 3, 15-21. [CrossRef]

96. Limoli, D.H.; Rockel, A.B.; Host, K.M.; Jha, A.; Kopp, B.T.; Hollis, T.; Wozniak, D.J. Cationic antimicrobial peptides promote microbial mutagenesis and pathoadaptation in chronic infections. PLoS Pathog. 2014, 10, e1004083. [CrossRef] [PubMed]

97. Carter, V.; Underhill, A.; Baber, I.; Sylla, L.; Baby, M.; Larget-Thiery, I.; Zettor, A.; Bourgouin, C.; Langel, U.; Faye, I.; et al. Killer bee molecules: antimicrobial peptides as effector molecules to target sporogonic stages of Plasmodium. PLoS Pathog. 2013, 9, e1003790. [CrossRef] [PubMed]

98. Lee, J.K.; Park, Y.J.; Kum, K.Y.; Han, S.H.; Chang, S.W.; Kaufman, B.; Jiang, J.; Zhu, Q.; Safavi, K.; Spangberg, L. Antimicrobial efficacy of a human beta-defensin-3 peptide using an Enterococcus faecalis dentine infection model. Int. Endod. J. 2013, 46, 406-412. [CrossRef] [PubMed]

99. Santos, R.; Gomes, D.; Macedo, H.; Barros, D.; Tiberio, C.; Veiga, A.S.; Tavares, L.; Castanho, M.; Oliveira, M. Guar gum as a new antimicrobial peptide delivery system against diabetic foot ulcers Staphylococcus aureus isolates. J. Med. Microbiol. 2016, 65, 1092-1099. [CrossRef] 
100. Gawande, P.V.; Leung, K.P.; Madhyastha, S. Antibiofilm and antimicrobial efficacy of DispersinB(R)-KSL-W peptide-based wound gel against chronic wound infection associated bacteria. Curr. Microbiol. 2014, 68, 635-641. [CrossRef]

101. Saeed, S.; Zafar, J.; Khan, B.; Akhtar, A.; Qurieshi, S.; Fatima, S.; Ahmad, N.; Irfanullah, J. Utility of (9)(9)mTc-labelled antimicrobial peptide ubiquicidin (29-41) in the diagnosis of diabetic foot infection. Eur. J. Nucl. Med. Mol. Imaging 2013, 40, 737-743. [CrossRef]

102. Galkowska, H.; Olszewski, W.L.; Wojewodzka, U. Expression of natural antimicrobial peptide beta-defensin-2 and Langerhans cell accumulation in epidermis from human non-healing leg ulcers. Folia Histochem. Cytobiol. 2005, 43, 133-136.

103. Lipsky, B.A.; Holroyd, K.J.; Zasloff, M. Topical versus systemic antimicrobial therapy for treating mildly infected diabetic foot ulcers: a randomized, controlled, double-blinded, multicenter trial of pexiganan cream. Clin. Infect. Dis. 2008, 47, 1537-1545. [CrossRef]

104. Sherman, R.A. Maggot therapy for treating diabetic foot ulcers unresponsive to conventional therapy. Diabetes Care 2003, 26, 446-451. [CrossRef]

105. Hassan, M.I.; Hammad, K.M.; Fouda, M.A.; Kamel, M.R. The using of Lucilia cuprina maggots in the treatment of diabetic foot wounds. J. Egypt Soc. Parasitol. 2014, 44, 125-129. [CrossRef]

106. Gilead, L.; Mumcuoglu, K.Y.; Ingber, A. The use of maggot debridement therapy in the treatment of chronic wounds in hospitalised and ambulatory patients. J. Wound Care 2012, 21, 78-85. [CrossRef] [PubMed]

107. De Alencar Fonseca Santos, J.; Campelo, M.B.D.; de Oliveira, R.A.; Nicolau, R.A.; Rezende, V.E.A.; Arisawa, E.A.L. Effects of Low-Power Light Therapy on the Tissue Repair Process of Chronic Wounds in Diabetic Feet. Photomed. Laser Surg. 2018, 36, 298-304. [CrossRef] [PubMed]

108. Kaviani, A.; Djavid, G.E.; Ataie-Fashtami, L.; Fateh, M.; Ghodsi, M.; Salami, M.; Zand, N.; Kashef, N.; Larijani, B. A randomized clinical trial on the effect of low-level laser therapy on chronic diabetic foot wound healing: a preliminary report. Photomed. Laser Surg. 2011, 29, 109-114. [CrossRef] [PubMed]

109. Katari, R.; Peloso, A.; Orlando, G. Tissue engineering and regenerative medicine: semantic considerations for an evolving paradigm. Front. Bioeng. Biotechnol. 2014, 2, 57. [CrossRef] [PubMed]

110. Veves, A.; Falanga, V.; Armstrong, D.G.; Sabolinski, M.L.; Apligraf Diabetic Foot Ulcer, S. Graftskin, a human skin equivalent, is effective in the management of noninfected neuropathic diabetic foot ulcers: a prospective randomized multicenter clinical trial. Diabetes Care 2001, 24, 290-295. [CrossRef]

111. Joao De Masi, E.C.; Campos, A.C.; Joao De Masi, F.D.; Ratti, M.A.; Ike, I.S.; Joao De Masi, R.D. The influence of growth factors on skin wound healing in rats. Braz. J. Otorhinolaryngol. 2016, 82, 512-521. [CrossRef]

112. Hong, J.P.; Jung, H.D.; Kim, Y.W. Recombinant human epidermal growth factor (EGF) to enhance healing for diabetic foot ulcers. Ann. Plast Surg. 2006, 56, 394-398. [CrossRef]

113. Laato, M.; Kähäri, V.M.; Niinikoski, J.; Vuorio, E. Epidermal growth factor increases collagen production in granulation tissue by stimulation of fibroblast proliferation and not by activation of procollagen genes. Biochem. J. 1987, 247, 385-388. [CrossRef]

114. Metcalfe, A.D.; Ferguson, M.W. Harnessing wound healing and regeneration for tissue engineering. Biochem. Soc. Trans. 2005, 33, 413-417. [CrossRef]

115. Choi, S.M.; Lee, K.M.; Kim, H.J.; Park, I.K.; Kang, H.J.; Shin, H.C.; Baek, D.; Choi, Y.; Park, K.H.; Lee, J.W. Effects of structurally stabilized EGF and bFGF on wound healing in type I and type II diabetic mice. Acta Biomater. 2017, 66, 325-334. [CrossRef]

116. Sridharan, K.; Sivaramakrishnan, G. Growth factors for diabetic foot ulcers: Mixed treatment comparison analysis of randomized clinical trials. Br. J. Clin. Pharmacol. 2017, 84, 434-444. [CrossRef] [PubMed]

117. Ertugrul, B.M.; Lipsky, B.A.; Guvenc, U. An Assessment of Intralesional Epidermal Growth Factor for Treating Diabetic Foot WoundsThe First Experiences in Turkey. J. Am. Podiatr. Med. Assoc. 2017, 107, 17-29. [CrossRef] [PubMed]

118. Marfia, G.; Navone, S.E.; Di Vito, C.; Ughi, N.; Tabano, S.; Miozzo, M.; Tremolada, C.; Bolla, G.; Crotti, C.; Ingegnoli, F.; et al. Mesenchymal stem cells: Potential for therapy and treatment of chronic non-healing skin wounds. Organogenesis 2015, 11, 183-206. [CrossRef] [PubMed]

119. Cao, Y.; Gang, X.; Sun, C.; Wang, G. Mesenchymal Stem Cells Improve Healing of Diabetic Foot Ulcer. J. Diabetes Res. 2017, 2017, 9328347. [CrossRef]

120. Seo, E.; Lim, J.S.; Jun, J.B.; Choi, W.; Hong, I.S.; Jun, H.S. Exendin-4 in combination with adipose-derived stem cells promotes angiogenesis and improves diabetic wound healing. J. Transl. Med. 2017, 15, 35. [CrossRef] 
121. Kim, J.W.; Lee, J.H.; Lyoo, Y.S.; Jung, D.I.; Park, H.M. The effects of topical mesenchymal stem cell transplantation in canine experimental cutaneous wounds. Vet. Dermatol. 2013, 24, 242-e53. [CrossRef]

122. Han, S.K.; Kim, H.S.; Kim, W.K. Efficacy and safety of fresh fibroblast allografts in the treatment of diabetic foot ulcers. Dermatol. Surg. 2009, 35, 1342-1348. [CrossRef]

123. Werner, S.; Krieg, T.; Smola, H. Keratinocyte-fibroblast interactions in wound healing. J. Invest. Dermatol. 2007, 127, 998-1008. [CrossRef]

124. Wu, Z.; Tang, Y.; Fang, H.; Su, Z.; Xu, B.; Lin, Y.; Zhang, P.; Wei, X. Decellularized scaffolds containing hyaluronic acid and EGF for promoting the recovery of skin wounds. J. Mater. Sci. Mater. Med. 2015, 26, 5322. [CrossRef]

125. Gugerell, A.; Pasteiner, W.; Nurnberger, S.; Kober, J.; Meinl, A.; Pfeifer, S.; Hartinger, J.; Wolbank, S.; Goppelt, A.; Redl, H.; et al. Thrombin as important factor for cutaneous wound healing: comparison of fibrin biomatrices in vitro and in a rat excisional wound healing model. Wound Repair Regen. 2014, 22, 740-748. [CrossRef]

126. Momeni, M.; Zarehaghighi, M.; Hajimiri, M.; Khorasani, G.; Dinarvand, R.; Nekookar, A.; Sodeifi, N.; Khosravani, P.; Shayanasl, N.; Ebrahimi, M. In vitro and in vivo investigation of a novel amniotic-based chitosan dressing for wound healing. Wound Repair Regen. 2018, 26, 87-101. [CrossRef] [PubMed]

127. Straccia, M.C.; d'Ayala, G.G.; Romano, I.; Oliva, A.; Laurienzo, P. Alginate hydrogels coated with chitosan for wound dressing. Mar. Drugs 2015, 13, 2890-2908. [CrossRef] [PubMed]

128. Goins, A.; Ramaswamy, V.; Dirr, E.; Dulany, K.; Irby, S.; Webb, A.; Allen, J. Development of poly (1,8 octanediol-co-citrate) and poly (acrylic acid) nanofibrous scaffolds for wound healing applications. Biomed. Mater. 2017, 13, 015002. [CrossRef] [PubMed]

129. Miyaguchi, S.I.; Horii, A.; Kambara, R.; Takemoto, N.; Akazawa, H.; Takahashi, N.; Baba, H.; Inohara, H. Effects of Covering Surgical Wounds with Polyglycolic Acid Sheets for Posttonsillectomy Pain. Otolaryngol. Head Neck Surg. 2016, 155, 876-878. [CrossRef]

130. Shin, Y.C.; Shin, D.M.; Lee, E.J.; Lee, J.H.; Kim, J.E.; Song, S.H.; Hwang, D.Y.; Lee, J.J.; Kim, B.; Lim, D.; et al. Hyaluronic Acid/PLGA Core/Shell Fiber Matrices Loaded with EGCG Beneficial to Diabetic Wound Healing. Adv. Healthc. Mater. 2016, 5, 3035-3045. [CrossRef]

131. Chong, E.J.; Phan, T.T.; Lim, I.J.; Zhang, Y.Z.; Bay, B.H.; Ramakrishna, S.; Lim, C.T. Evaluation of electrospun $\mathrm{PCL} /$ gelatin nanofibrous scaffold for wound healing and layered dermal reconstitution. Acta Biomater. 2007, 3, 321-330. [CrossRef]

132. Koehler, J.; Verheyen, L.; Hedtrich, S.; Brandl, F.P.; Goepferich, A.M. Alkaline poly(ethylene glycol)-based hydrogels for a potential use as bioactive wound dressings. J. Biomed. Mater. Res. A 2017, 105, 3360-3368. [CrossRef]

133. Kim, J.W.; Kim, M.J.; Ki, C.S.; Kim, H.J.; Park, Y.H. Fabrication of bi-layer scaffold of keratin nanofiber and gelatin-methacrylate hydrogel: Implications for skin graft. Int. J. Biol. Macromol. 2017, 105, 541-548. [CrossRef]

134. Kaisang, L.; Siyu, W.; Lijun, F.; Daoyan, P.; Xian, C.J.; Jie, S. Adipose-derived stem cells seeded in Pluronic F-127 hydrogel promotes diabetic wound healing. J. Surg. Res. 2017, 217, 63-74. [CrossRef]

135. Frykberg, R.G.; Cazzell, S.M.; Arroyo-Rivera, J.; Tallis, A.; Reyzelman, A.M.; Saba, F.; Warren, L.; Stouch, B.C.; Gilbert, T.W. Evaluation of tissue engineering products for the management of neuropathic diabetic foot ulcers: an interim analysis. J. Wound Care 2016, 25, S18-S25. [CrossRef]

136. Falanga, V.; Isaacs, C.; Paquette, D.; Downing, G.; Kouttab, N.; Butmarc, J.; Badiavas, E.; Hardin-Young, J. Wounding of bioengineered skin: Cellular and molecular aspects after injury. J. Invest. Dermatol. 2002, 119, 653-660. [CrossRef] [PubMed]

137. Gilligan, A.M.; Waycaster, C.R.; Milne, C.T. Cost Effectiveness of Becaplermin Gel on Wound Closure for the Treatment of Pressure Injuries. Wounds 2018, 30, 197-204. [PubMed]

138. Wainwright, D.J. Use of an acellular allograft dermal matrix (AlloDerm) in the management of full-thickness burns. Burns 1995, 21, 243-248. [CrossRef]

139. Hart, C.E.; Loewen-Rodriguez, A.; Lessem, J. Dermagraft: Use in the Treatment of Chronic Wounds. Adv. Wound Care (New Rochelle) 2012, 1, 138-141. [CrossRef] 
140. Towler, M.A.; Rush, E.W.; Richardson, M.K.; Williams, C.L. Randomized, Prospective, Blinded-Enrollment, Head-To-Head Venous Leg Ulcer Healing Trial Comparing Living, Bioengineered Skin Graft Substitute (Apligraf) with Living, Cryopreserved, Human Skin Allograft (TheraSkin). Clin. Podiatr. Med. Surg. 2018, 35, 357-365. [CrossRef]

141. Still, J.; Glat, P.; Silverstein, P.; Griswold, J.; Mozingo, D. The use of a collagen sponge/living cell composite material to treat donor sites in burn patients. Burns 2003, 29, 837-841. [CrossRef]

142. Carsin, H.; Ainaud, P.; Le Bever, H.; Rives, J.; Lakhel, A.; Stephanazzi, J.; Lambert, F.; Perrot, J. Cultured epithelial autografts in extensive burn coverage of severely traumatized patients: a five year single-center experience with 30 patients. Burns 2000, 26, 379-387. [CrossRef]

143. Woodroof, A.; Phipps, R.; Woeller, C.; Rodeheaver, G.; Naughton, G.K.; Piney, E.; Hickerson, W.; Branski, L.; Holmes, J.H.T. Evolution of a Biosynthetic Temporary Skin Substitute: A Preliminary Study. Eplasty 2015, 15, e30.

144. Spater, T.; Frueh, F.S.; Metzger, W.; Menger, M.D.; Laschke, M.W. In vivo biocompatibility, vascularization, and incorporation of Integra((R)) dermal regenerative template and flowable wound matrix. J. Biomed. Mater. Res. B Appl. Biomater. 2018, 106, 52-60. [CrossRef]

145. Kumar, R.J.; Kimble, R.M.; Boots, R.; Pegg, S.P. Treatment of partial-thickness burns: a prospective, randomized trial using Transcyte. ANZ J. Surg. 2004, 74, 622-626. [CrossRef]

146. Benbow, M. Oasis: An innovative alternative dressing for chronic wounds. Br. J. Nurs. 2001, 10, 1489-1492. [CrossRef] [PubMed]

147. Deneve, J.L.; Turaga, K.K.; Marzban, S.S.; Puleo, C.A.; Sarnaik, A.A.; Gonzalez, R.J.; Sondak, V.K.; Zager, J.S. Single-institution outcome experience using $\operatorname{AlloDerm}(\mathrm{R})$ as temporary coverage or definitive reconstruction for cutaneous and soft tissue malignancy defects. Am. Surg. 2013, 79, 476-482. [PubMed]

148. Becker, S.; Saint-Cyr, M.; Wong, C.; Dauwe, P.; Nagarkar, P.; Thornton, J.F.; Peng, Y. AlloDerm versus DermaMatrix in immediate expander-based breast reconstruction: A preliminary comparison of complication profiles and material compliance. Plast. Reconstr. Surg. 2009, 123, 16. [CrossRef]

149. Derwin, K.A.; Baker, A.R.; Spragg, R.K.; Leigh, D.R.; Iannotti, J.P. Commercial extracellular matrix scaffolds for rotator cuff tendon repair. Biomechanical, biochemical, and cellular properties. J. Bone Joint Surg. Am. 2006, 88, 2665-2672. [CrossRef] [PubMed]

150. Meaume, S.; Gemmen, E. Cost-effectiveness of wound management in France: Pressure ulcers and venous leg ulcers. J. Wound Care 2002, 11, 219-224. [CrossRef]

(C) 2019 by the authors. Licensee MDPI, Basel, Switzerland. This article is an open access article distributed under the terms and conditions of the Creative Commons Attribution (CC BY) license (http://creativecommons.org/licenses/by/4.0/). 